\title{
Sosyal Medya Pazarlama Aktiviteleri ile Satın Alma Niyeti Arasındaki İlişkide Marka Kişiliğinin Rolü: Literatür Araştırması*
}

\section{Mustafa Seckin Salvarli ${ }^{\mathrm{a}}$, Burak Kartal $^{\mathrm{b}}$}

Öz: Dijital dünyadaki gelişmeler, iş ortamında beliren değişikliklerle başa çıkmada işletmelerin izlediği stratejiyi değiştirmiş, dolayısıyla pazarlamacıların müșteri ile temas etme yolları, kaynakları ve müşteriyi çekme ya da elde tutma için kullandıkları yöntemler de değişmiştir. Bu değişimler temelde, sanal dünyada müşterinin ihtiyaçlarının, özelliklerinin, fikirlerinin, ilişki örüntülerinin ve sorunlarının anlaşılmasını sağlayacak ilişkiler geliştirmeyi gerektirmiştir. Geliştirilen ilişkiler sayesinde, tüketicilerin satın alma niyetleri ile satın alma aşamasında hangi faktörlere önem verdikleri anlaşılmaya başlanmıştır. Literatür taramasına dayalı bu çalışmada, müşterilerle ilişki kurmada sağladığı faydaların yanı sıra birçok farklı avantaja sahip sosyal medya pazarlama faaliyetlerinin ve marka kişiliğinin, tüketicinin ilgili markayı satın alma niyeti üzerindeki doğrudan etkileri incelenmiştir. Bu çalışmayla, marka kişiliğinin sosyal medya pazarlama faaliyetleri ile tüketicinin satın alma niyeti arasındaki ilişkide olası aracı etkisinin incelenmesine duyulan ihtiyaç vurgulanmakta ve bu konuda yapılacak öncül çalışmalara motivasyon kaynağı olması amaçlanmaktadır.

\section{The Role of Brand Personality in the Relationship Between Social Media Marketing Activities and Purchase Intention: A Literature Research}

Abstract: The developments in the digital world have changed the strategy followed by companies in dealing with changes in the business environment. Therefore, the way marketers touchpoints with the customer, the resources, and the methods they use to attract or retain the customer have changed. These changes essentially required developing relationships that would enable the customer to understand the needs, characteristics, ideas, relationship patterns, and problems in the virtual world. Thanks to the relationships that have been developed, it has begun to be understood the purchasing intentions of the consumers and the factors they attach importance to the purchasing phase. Based on the literature review, this study examines the effects of social media marketing activities, which have many different advantages besides their benefits in establishing relationships with customers, and brand personality on consumers' intention to purchase the relevant brand. With this study, the need to examine the possible mediating effect of brand personality on the relationship between social media marketing activities and the consumer's purchase intention is emphasized, and it is aimed to be a source of motivation for conducting studies on this subject.
Anahtar Sözcükler: Sosyal Medya, Sosyal Medya Pazarlama Aktiviteleri, Marka, Marka Kişiliği, Tüketici Satın Alma Niyeti

JEL: M30, M31

$\begin{array}{ll}\text { Geliş } & : \text { 22 Mart } 2021 \\ \text { Düzeltme } & : \text { 11 Mayıs 2021 } \\ \text { Kabul } & : \text { 08 Haziran } 2021 \\ \text { Tür } & : \text { Derleme }\end{array}$

Keywords: Social Media, Social Media Marketing Activities, Brand, Brand Personality, Consumer Purchase Intention

JEL: M30, M31

Received : 22 March 2021

Revised : 11 May 2021

Accepted : 08 June 2021

Type : Review

a PhD. Student, Manisa Celal Bayar University, Institute of Social Sciences, Department of Business Administration, Manisa, Turkiye, seckinsalvarli@gmail.com (ORCID ID: 0000-0002-5306-5655)

b Assoc. Prof., PhD., Manisa Celal Bayar University, Institute of Social Sciences, Department of Business Administration, Manisa, Turkiye, burakkartal@yahoo.com (ORCID ID: 0000-0001-8556-091x) 


\section{Giriş}

Tüketici davranışlarındaki değişiklikler, firmaların dijital alandaki pazarlama stratejilerini yeniden değerlendirmelerini gerektirmiştir (Tiago ve Veríssimo, 2014: 705). Tüketici açısından internetin bir pazarlık yeri olduğunu öne süren ilk görüşlerin aksine, internet daha sık olarak üstün bir hizmet arama/sağlama ve tüketici ilişkilerini geliştirme alanı olarak görülmeye başlanmıştır (Kryvinska, Kaczor, Strauss ve Gregus, 2015).

Dijital pazarlama, geleneksel olarak bilinen medyadan farklı yöntemler ile markanın ve yapılan işin tanıtımının yapıldığı ve tüm pazarlama faaliyetlerine destek vermek amacıyla internet, mobil ve interaktif platformların kullanıldığı pazarlama faaliyetlerini kapsamaktadır (Chaffey ve Smith, 2013). Smith (2007), Dijital Pazarlama Enstitüsü'nün dijital pazarlamayı, hedeflenmiş ve ölçülebilir bir iletişimin, dijital teknoloji yardımıyla pazarlama amaçlarına ulaşılabilecek şekilde kullanılması olarak tanımladığını belirtmektedir. Yani, teknolojinin kullanılarak tanıtım faaliyetlerinde daha etkili, kapsamlı ve geniş kitleleri hedefler haline getiren, internet temelinde bir pazarlama biçimidir (Merisavo, 2006).

Dijital pazarlamadaki büyüme, büyük ölçüde teknolojideki hızlı ilerlemeler ve değişen pazar dinamiklerinden kaynaklanmaktadır (Mort ve Drennan, 2002: 9). Buna göre, geliş̧miş dünyada birçok şirket dijital pazarlamanın önemini kabul etmiş (Parsons, Zeisser ve Waitman, 1996: 185) ve insanlar kendilerini giderek daha fazla dijital ve sosyal medyaya maruz bırakarak sanal dünyanın içinde konumlandırmaya başlamışlardır. Bu sayede, dijital dünya, insanların ürünler hakkında bilgi aradıkları, onları satın aldıkları, tükettikleri ve deneyimleri hakkında başkalarıyla iletişim kurdukları bir mecra halini almıştır (Stephen, 2016: 17). Pazarlamacılar, dijital pazarlama kanallarının kullanımını artırarak bu temel değişime yanıt vermeyi amaçlamakta (Stephen, 2016: 17), pazarlamanın ilk ve en önemli adımlarından biri olarak kabul edilen "marka bilinci oluşturma" sürecinde dijital pazarlama araçlarını verimli şekilde kullanmaya çabalamakta (Çizmeci ve Ercan, 2015: 150) ve gelecekteki pazarlama uğraşılarının büyük ölçüde dijital ortamlarda, özellikle de sosyal medya ve mobil ortamlarda gerçekleştirileceğini öngörmektedirler.

Bu gelişmeler göz önüne alındığında, tüketici davranışlarının dijital ortamlarda incelenmesi ve anlamlandırıması gerekliliği aşikardır (Stephen, 2016: 17). Buradan hareketle bu çalışmada, dijital pazarlamanın önemli bir kolu olan sosyal medya pazarlama aktivitelerinin tüketicilerin ürünleri satın alma niyetlerine etkisinin ve markanın kişiliğine dair tüketici algısının bu ilişkideki rolünün araştırılması amaçlanmaktadır.

\section{Sosyal Medya Pazarlama Aktiviteleri}

Sosyal medya, paylaşılan içerik, görüş, perspektif ve medyanın yanı sıra tüketiciler ile kuruluşlar arasındaki ilişkileri ve bağlantıları içermektedir (Nair, 2011: 45). Bu kapsamda kullanılan araçlar arasında bloglar, sohbet odaları, tüketici ürün ve şirket derecelendirme siteleri, tartışma panoları, sosyal ağ siteleri, vlog'lar (video günlükleri), widget'lar (ekran araçları) ve wiki'ler (bilgi sayfaları) bulunmaktadır. Eski moda tek yönlü iletişimin zaman, mekân, ortam gibi tüm kısıtlamalarının ortadan kalktığı ve çift yönlü doğrudan iletişime dönüşümün yaşandığı bu uygulamalar (Racolta-Paina ve Luca, 2010: 87), markalar ve tüketicilerin karşılıklı yarar için kesintisiz iletişim kurabildiği ortamlar halini almıştır. Bu doğrultuda ortaya çıkan sosyal medya pazarlaması, yeni bir alandır ve çevrimiçi sosyal medya aracılığıyla mal, hizmet, bilgi ve fikirlerin pazarlanması ile ilgili yeni bir iş uygulaması olarak görülmektedir. Sosyal medya pazarlaması, sosyal ağ, sanal dünyalar, kullanıcı tarafından oluşturulan ürün incelemeleri, blog yazıları, içerik ve sosyal haber sitelerinin RSS (doküman takip sistemi) beslemeleri, podcast'ler, oyunlar ve tüketici tarafından üretilen reklamlar dahil olmak üzere geniş bir reklam harcama kategorisidir. Diğer bir deyişle, bu pazarlama türü, markanın müşterilerle daha iyi bağlantı kurmasına, web sitelerine trafik oluşturmasına ve farkındalığı artırmasına ve böylece genel satışları artırmasına yardımcı olan belirli bir markanın resmi hesabının pazarlama uygulaması ve yönetimini ifade etmektedir (Chiang, Wong ve Huang, 2019: 115). Ayrıca, markalaşma ve iletişim hedeflerini karşılamak için "sosyal ağlar (örneğin Youtube, Myspace ve Facebook), sanal dünyalar (örneğin Second Life, There ve Kaneva), sosyal fikir paylaşım siteleri (örneğin Eopinions) ve sosyal haber siteleri dahil olmak üzere sosyal bağlamın kültürel yanının kullanıldığı çevrimiçi bir reklamcılık biçimi" olarak da tanımlanmaktadır (Tuten, 2008). Bir bakıma, e-posta bültenleri ve çevrimiçi reklam kampanyaları gibi 
geleneksel web tabanlı tanıtım stratejilerini tamamlayan çevrimiçi pazarlama faaliyetlerinin alt kümesidir (Barefoot ve Szabo, 2010). Bu pazarlama türünün uygulanma kolaylığı ya da internetin hızlı yapısı gibi umut veren özellikleri, birçok şirketi katılmaya motive etmiş (Carim ve Warwick, 2013: 521); işletmeleri, tüketicilere ulaşmanın etkileşimli, odaklanmış ve ölçülebilir bir yolu olarak bu medya platformlarını hedefleyen stratejileri uygulamaya yöneltmiş (Lamberton ve Stephen, 2016: 146-147); sosyal medyayı pazarlama stratejilerinin önemli bir parçası haline getirmiştir (Zhou ve Wang, 2014: 27). İşletmeler sosyal medya pazarlama faaliyetleri sayesinde, kendi marka profillerini oluşturarak çevrimiçi müşteri yardımı sağlama, ürünleri veya hizmetleri hakkında bilgi verme ve özel fiyat teklifleri sunma gibi faaliyetlerde bulunabilmektedirler (Dineva, Breitsohl ve Garrod, 2017: 680). Ayrıca bir çok işletme sosyal medya kanallarındaki basit tıklamalarla kullanıcıları arasındaki çevrimiçi etkileşimleri kullanarak satın aldıklarını paylaşmaya teşvik etmektedir (So, Wu, Xiong ve King, 2018: 728)

Sosyal medya, tüketiciler arasında giderek yaygınlaşan ve popüler hale gelen bir mecra olmasının yanında (Kaplan ve Haenlein, 2010: 60), pazarlamacılara, geleneksel pazarlama ortamlarına kıyasla, müşterilerle iletişim kurma ve ağ oluşturma konusunda daha fazla fırsat sunmakta (Gros, 2012) ve işletmelerin gelirlerini arttırmalarına olanak sağlamaktadır (Wilson ve Abel, 2002: 85). Bu gelişmeler, müşterilere aktif rol yüklemiş, satın alma alışkanlıklarını şekillendirmiş ve "çevrimiçi tüketici" adı verilen yeni bir tüketici profilini ortaya çıkarmıştır (Racolta-Paina ve Luca, 2010: 91). Bu tüketiciler, geleneksel tüketicilere kıyasla sahip oldukları farklı satın alma alışkanlıkları sebebiyle e-ticaret dünyasında önemli bir rol üstlenmiştir. Şöyle ki, çevrimiçi tüketiciler markalarla sosyal ilişkiler kurmaya başlamış, mal ve hizmetlerin tasarımında ve üretiminde aktif hale gelmişlerdir (Wave 8, 2014). Bu doğrultuda, işletmelerin küresel ortamda rekabet avantajı elde etmek ve dünya genelindeki kitlelerini arttırmak için bu tür tüketicilerin ihtiyaçlarını, özelliklerini, ilişkilerini ve satın alma niyetlerini anlamaları gerekmiştir. Tüketicilerin sosyal ağlardaki davranışları ve profilleri büyük miktarda veri kaynağı haline gelmeye başlamış, pazarlamacılar e-pazarlamanın önemi sebebiyle tüketicilerin davranışlarını ve ilişkilerini anlamada bu verileri kullanmaya başlamışlardır (Çetinkaya ve Özdemir, 2014). E-pazarlama, pazarlamacıların tüketicilerin ihtiyaçlarını ve isteklerini dinlemesi, alt tüketici gruplarını analiz etmesi, etkileyicilerin ve kanaat önderlerinin tespit edilmesi için yeni bir pencere açılmasına olanak sağlamıştır (Neti, 2011).

Öte yandan, sosyal medya, müşteriler için en yeni ve güncel bilgi kaynağı haline gelmiştir (Hamid, Bukhari, Ravana, Norman ve ljab, 2016: 645). Günümüzde tüketiciler en son ürünlerden haberdar olmak, indirim almak, özel promosyonlara erişmek ve şirket hakkında daha fazla bilgi edinmek için favori markalarını Facebook, Instagram ve Twitter gibi sosyal medya platformlarından takip edebilmektedirler. Tüketicilerin sosyal medyaya zamanla artan bu ilgisi, markaların karşılarında ulaşmaları gereken bir kitle olduğunu fark etmelerini sağlamıştır. Çünkü, sosyal medyanın sunduğu imkanlar sayesinde tüketiciler, dünyanın herhangi bir yerindeki herhangi bir kişiyle deneyimlerini paylaşabilmektedir (Kozinets, De Valck, Wojnicki ve Wilner, 2010: 71). Diğer bir deyişle, sosyal medya, bireyin yüz binlerce kişiyle bir ürün ve bu ürünü sağlayan şirket hakkında iletişim kurmasını mümkün kılmıştır. Tüketiciler, özellikle çevrimiçi yorumlar ve elektronik sosyal ağ web siteleri aracılığıyla diğer tüketicilere danışarak alternatif bilgi kaynaklarından ürün ve hizmetler hakkında bilgi alabilmektedirler (Clemons, 2009: 47). Bu durum, tüketicilerin bir mal veya hizmet satın alma zamanı geldiğinde, başkalarının görüşlerini tekrar tekrar alma intiyaçlarını (Akar, 2010: 114-115) karşılar niteliktedir. Öyle ki, sanal toplulukların tüketicilerin davranışlarını etkilemede önemli bir rol üstlendiği savunulmaktadır (Fotis, Buhalis ve Nicos, 2012). Sosyal medya bir bakıma tüketicileri işletmeler, mallar ve hizmetler hakkında çevrimiçi bilgiler üreten, düzenleyen ve paylaşan pazarlamacılara ve reklam verenlere dönüştürmektedir (Akar ve Topçu, 2011: 40). Bu sayede, tüketiciden tüketiciye olan iletişimin piyasadaki etkisi de oldukça genişlemiştir (Mangold ve Faulds, 2009: 358).

\section{Sosyal Medya Pazarlama Aktiviteleri ile Tüketici Satın Alma Niyeti ilişkisi}

Tutum kavramı, "bir kişinin olumlu veya olumsuz değerlendirmesi, duygusu ve bazı nesneler veya fikirlere yönelik eylem eğilimleri" olarak tanımlanmaktadır. Buradan hareketle, insanların davranışlarının tutumlarından etkilendiği ve benzer nesnelere karşı oldukça tutarlı şekilde davrandıkları düşünülmektedir. Tutum kavramına pazarlama açısından bakıldığında ise bir kişinin bir markaya karşı tutumu ne kadar iyi olursa, 
ürünü satın alma olasılığının da o kadar yüksek olacağı belirtilmektedir (Kotler ve Keller, 2006). Tersine, tutum ne kadar olumsuz olursa da ürünü alma olasılığı o kadar azalacaktır (Chiou, Chen, Huang, Huang ve Hu, 2008). Genel olarak bakıldığında, bazı tüketiciler markaların statü ve prestij sembolü olarak görüldüğü marka bilincine sahipken, bazıları ise para ile en iyi değeri elde etme amacıyla markaların fiyatlarını kontrol ettikleri ve karşılaştırdıkları değer bilincine sahiptirler (Hennig-Thurau, Gwinner, Walsh ve Gremler, 2004: 43; Nambisan ve Baron, 2007: 45-46). Ancak, her iki tüketici profili için de bir markaya dair tutum oluşturulmasında sosyal medya pazarlama stratejilerinden yararlanılabilmektedir. Bunun yanında, sosyal medya pazarlaması üzerinde yürütülen markalaşma faaliyetleri sayesinde yaratılan marka bilinirliği, markayı pazarda tanınır kılmaktadır. Tüketicinin ilgili markayı pazardaki diğer benzer markalardan ayırabilmesini, bu markanın temsil ettiği sembolik içeriği ve markanın vaat ettiği sosyal konumu algılayabilmesini sağlamaktadır (Aaker, 1996: 102-103). Dahası, yine sosyal medya pazarlama faaliyetleri sonucunda oluşturulan güçlü tüketici-marka ilişkisi ve marka bağlılığı ya da sadakati ile tüketicinin ilgili markaya dair farklı bir yol aracılığıyla olumlu tutum geliştirmesi sağlanmaktadır. Bunun yanı sıra, bağlı olduğu markayı sıklıkla satın alması, satın almaya devam etmesi ve uzun süreler boyunca o markayı kullanması sağlanabilmektedir (Odabaşı ve Barış, 2002).

Müşterilerin satın alma sürecinde (bilgi toplama, alternatifleri değerlendirme ve en iyi seçeneği seçme) ve hatta kendi deneyimlerini paylaşma gibi satın alma sonrası süreçte sosyal medyayı kullandıkları bilinmektedir (Drews ve Schemer, 2010). Bu da aslında, müşterinin satın alma kararı sırasında kendisine dair bilgileri geri vermesi anlamına gelmekte ve davranışları ile algısı, bu platformlar üzerinden yayınlanan bilgilerle güçlü bir şekilde tahmin edilmektedir (Erkan ve Evans, 2016: 48). Yani, bir ağın verilerini değerlendirerek firmalar ağın kullanıcıları hakkında önemli bilgiler sağlayabilmekte; bu da söz konusu site için en iyi sosyal medya aktivitelerinin belirlenmesinde yardımcı olmaktadır (Hill, Provost ve Volinsky, 2006; 257). Ayrıca, Hill, Provost ve Volinsky (2006) tarafından yürütülen bir araştırmada, firmaların, dikkate aldıkları ağ (ör. Facebook, Instagram, Pinterest vb.) verilerini inceleyerek satın alınma olasılıklarını hesaplayabildikleri de gösterilmiştir.

Yukarıda bahsedilen gelişmeler pazarlama uzmanlarını sosyal medya pazarlamasının tüketici satın alma niyeti üzerindeki etkisini detaylı analiz etmeye yöneltmiştir (Gautam ve Sharma, 2017: 873). Bu doğrultuda, literatürde tüketicilerin farklı bakış açıları ve satın alma davranışlarına odaklanan birçok çalışma yer almakta (Akar ve Nasir, 2015), sosyal medyanın çevrimiçi alışverişe etkisi incelenmekte (Vinerean, Cetina, Dumitrescu ve Tichindelean, 2013) ve çevrimiçi tüketicilere uygun sosyal medya pazarlama stratejilerinin epazarlamacılar açısından yararı vurgulanmaktadır (Akar ve Dalgic, 2018: 482). Gautam ve Sharma (2017: 884885)'nın sosyal medya pazarlamasının tüketici satın alma niyeti üzerindeki etkisine odaklandıkları çalışmalarında, bu iki etmen arasında istatistiksel olarak anlamlı düzeyde ve olumlu yönde bir ilişki olduğu saptanmıştır. Bloglara ve online dergilere verilen tüketici tepkilerinin değerlendirildiği bir çalışmada, bloglar ve online magazin içeriğindeki bilgiye maruz kalan tüketicilerin daha güçlü marka tutumu geliştirdikleri ve daha yüksek satın alma niyeti belirttikleri görülmüştür (Colliander ve Dahlen, 2011). Benzer şekilde, yürütülen birçok araştırmada da bu ilişki desteklenmiş, sosyal ağ pazarlamasının tüketicilerin satın alma niyetini olumlu yönde yordadığı saptanmıştır (Dehghani ve Tumer, 2015: 600; Toor, Husnain ve Hussain, 2017: 187; Harun ve Husin, 2019: 118-120). Detaylı incelendiğinde, tüketicilerin satın alma niyetleri üzerinde "yerleşim", "pazarlama faaliyetleri", "deneyimsel pazarlama" ve "etkileşim" olmak üzere dört faktörün etkili olduğu görülmüştür (Mao, Zhu ve Sang, 2014). Ulusal bir çalışma ise, özellikle kişiselleştirme ve eğlence boyutlarının yeniden satın alma niyeti üzerinde etkili olduğunu göstermiştir (Bilgin, 2018: 140-142). Ayrıca, sosyal medyada yapılan pazarlama faaliyetlerinin ve satış promosyonlarının maksimum sayıda tüketiciyi çekmesi ve ulaşması için güçlü ve düşük maliyetli bir platform olduğu sonucuna varılmıştır (Chaturvedi ve Gupta, 2014: 6-7). Dahası, sosyal medya pazarlamasında reklam faktörünün göz önünde bulundurularak çevrimiçi satın alma niyetinin analiz edildiği çalışmalar da mevcuttur. Örneğin, Luna-Nevarez ve Torres (2015: 14-16) tarafından yürütülen bir araştırmada, tüketicilerin sosyal medya reklamcılı̆̆ına yönelik tutumları ile çevrimiçi satın alma niyetleri arasında olumlu yönde bir ilişki bulgulanmıştır. Sosyal medya platformları üzerinden sunulan bu reklamlar daha detaylı incelendiğinde, reklamların algılanan yararının, yaratıcı ve ilgi çekici olma düzeyinin, etkileşimselliğinin, bilgilendiriciliğinin ve tüketici tarafından ilişkili olarak algılanma düzeyinin ilgili ürünün satın alınma düzeyini olumlu yönde anlamlı düzeyde yordadığı görülmektedir (Alalwan, 2018: 71-73). 
Martínez-Navarro ve Bigné (2017: 64-66)'nın yaptıkları bir çalışmada ise sosyal ağlarda pazarlamacı tarafından üretilen içeriğin reklam değerine vurgu yapılmakta, bu faaliyetlerin elektronik ağızdan ağıza ve web sitesi ziyaret niyeti üzerindeki etkilerine ek olarak çevrimiçi satın alma üzerindeki olumlu etkileri de gösterilmektedir. Benzer şekilde, insanların bir ürün satın alırken sosyal medyadaki fikir liderlerinin görüşlerini dikkate aldıkları belirtilmekte ve işletmelere, müşterilerini sosyal medyada yayın yapmaya (pazarlama yapmaya) teşvik etmeleri önerilmektedir (Forbes ve Vespoli, 2013: 110).

Sosyal medya pazarlama faaliyetlerinin tüketici satın alma niyeti üzerindeki olumlu etkisine dair ulaşılan tüm bu bulgular, bu ilişkinin, tüketici satın alma davranışını etkileyen bazı faktörler tarafından etkilenebileceğini düşündürmüştür. Çünkü, tüketici satın alma davranışı tüketici özellikleri (Hidayat ve Diwasasri, 2013: 149), algılanan değer (Shaharudin, Pani, Mansor ve Elias, 2010: 75), algılanan risk, yarar ve kullanım kolaylığı (Faqih, 2013: 74-75) gibi birçok değişkeni içinde barındıran bir süreçtir. Benzer şekilde, yürütülen bir araştırma da, ürün kalitesi, marka ve reklamların tüketici satın alma niyetini etkileyen en önemli etmenler olduğunu bulgulamıştır (Mirabi, Akbariyeh ve Tahmasebifard, 2015: 271). Bu doğrultuda, Toor, Husnain ve Hussain (2017: 187) tarafından yapılan çalışma, sosyal ağ pazarlaması ile tüketicilerin satın alma niyetleri arasında saptanan bu olumlu ilişkide tüketici katılımının aracı rol üstlendiğini saptamıştır. Sosyal medya pazarlama faaliyetlerinin lüks moda markaların satın alınma niyeti üzerindeki etkisini inceleyen bir başka çalışmada, bu iki değişken arasında saptanan olumlu ilişkide, güven ve yakınlık boyutlarından oluşan tüketici ilişkileri faktörünün tam aracılık ettiği gösterilmiştir (Gautam ve Sharma, 2017: 883-884). Mao, Zhu ve Sang (2014) ise sosyal medya pazarlama faaliyetlerinin tüketici tarafından algılanan değeri ve riski etkileyerek satın alma niyetini yordadığını bulgulamıştır. Bir diğer çalışma da, sosyal medya pazarlama faaliyetlerinden biri olarak kullanılan reklamların marka imajı ve marka değerini olumlu yönde etkilediğini, marka imaj ve değerinin ise ilgili markanın satın alınma düzeyini arttırdığını göstermiştir (Dehghani ve Tumer, 2015: 599-600). Ayrıca, sosyal medya pazarlama aktivitelerinin marka sadakati üzerinde, yani markanın tekrarlı satın alınması üzerinde yarattığı olumlu etkide, marka farkındalığının ve değer farkındalığının aracı rol üstlendikleri bulgulanmıştır (Ismail, 2017: 135-136).

\section{Sosyal Medya Pazarlama Aktiviteleri ile Tüketici Satın Alma Niyeti Arasındaki iliş̧kide Marka Kişiliğinin Rolü}

\subsection{Marka Kişiliği}

Marka yönetimi literatüründe, marka kişiliği kavramından ilk söz eden 1970'li yıllarda Kapferer olmuştur. Kapferer'in yaptığı tanımda marka kişiliği, bir markanın dışarıya dönük olan yüzü ve markalarla ilişkilendirilen insani karakter özellikleri olarak tanımlanmışır. En yaygın tanım, marka kişiliğinin bir markayla ilişkili insan özellikleri kümesi olduğu şeklindedir. Aynı yıllarda, Markham, işletmelerde kişilik ölçeğinin kullanılması fikrini önermiştir (Wallenklint, 1998). Marka kişiliği, literatürde büyük ölçüde bir pazarlama yapısı olarak ele alınsa da insan kişiliğini ele alan bazı teorik temellere dayanmaktadır. Öyle ki marka kişiliği üzerine yapılan ilk araştırma McCrae ve John (1992) tarafından önerilen Beş Faktör Modelini (FFM) temel almaktadır. FFM, insan kişiliğinin temel yapısını dışa dönüklük, duygusal dengesizlik, deneyime açıklık, sorumluluk ve uyumluluk olmak üzere beş boyutta açıklamaktadır.

Marka kişiliğinin en çok bilinen ve kullanılan kavramsallaştırması Aaker (1997: 347) tarafından yapılmış ve "belirli bir markayla ilişkilendirilen insani özellikler dizisi" olarak tanımlanmıştır. Bu tanımın detayına inildiğinde, cinsiyet, yaş, sosyoekonomik sınıf gibi özelliklerin yanı sıra sıcaklık, ilgi ve duygusallık gibi klasik insani özelliklerin de göz önüne alındığı anlaşılmaktadır (Aaker, 1997). Aaker (1997), insan kişiliği araştırmalarında kilit bir yaklaşım olan özellik veya faktör yaklaşımını takip etmiş, marka kişiliğinin samimiyet, coşku/heyecan, yeterlilik/ustalık, seçkinlik ve sertlik/sağlamlık boyutlarının altında yer alan 42 özellik tarafından oluşturulduğunu önermiştir. Beş marka kişiliği boyutundan her biri 15 gruba ayrılmış ve 15 farklı grupta toplanan 42 kişilik özelliği ile toplam 309 kişilik özelliği oluşturulmuştur. Farklı kültürlere ait tüketiciler açısından, marka kişiliği boyutları arasında tutarlıık görüldüğü belirtilmektedir (Venable, Rose ve Gilbert, 2003). 
Animizm teorisine göre, tüketiciler bir markayı en azından yarı insanı içeren bir şey olarak algılamaktadır (Avis, 2012: 91). Marka kişiliği, marka imajının duygusal tarafına karşıık gelmekte, tüketicilerin marka ile tecrübelerinin tümü marka kişiliğinin oluşumunda etkili olmaktadır (Rajagopal, 2006: 59). Aslında tüketiciler, marka katma değerinin belirleyicileri olarak markanın kişilik boyutlarını uygulamakta ve bu da tüketicilerin kişiliğini onunla ifade etmesine olanak sağlamaktadır. Yani, markanın insani özellikleri (kişiliği) ile kişinin gerçek veya ideal benliği arasındaki uyum, marka tercihini arttırmaktadır (Aaker, 1997). Marka kişiliği, ürünlerin değerlendirilmesinde önemli bir araçtır ve markaya yönelik tutumu ve tüketici davranışını etkilemektedir (Valette-Florence, Guizani ve Merunka, 2011: 27).

\subsection{Sosyal Medya Pazarlama Aktiviteleri ile Marka Kişiliği iliş̧kisi}

Tüketici ile marka arasında oluşturulacak ilişkinin düzeyi arttıkça, tüketicinin ürünü tercih etme oranı yükselmekte ve zamanla bu tercih, tüketicide bağ|ılık oluşturmaktadır. Bu bağlılı̆ın oluşması için öncelikli olarak tüketicinin markayı benimsemesi, kişiselleştirmesi ve onunla arasında duygusal bir bağ kurması gerekmektedir. Bu kişiselleştirme ve benimsemenin sağlanmasında ise marka kişiliğinin rolü büyüktür (Yılmaz, 2007). Çünkü, tüketici gerçek ve ideal benliğini tanımlama aracı olarak, tercih ettiği markanın kişiliğini kullanmaktadır. Diğer bir deyişle, insanlar ne kadar genç ya da yaşlı olduklarını, ne kadar feminen ya da maskülen olduklarını, sosyal gruplarına ne kadar benzediklerini ya da ayrıldıklarını tanımlamada markaları kullanmaktadır (Özdemirci, 2004). Yani, tercih ettikleri markanın kişiliği bir nevi kendilerini ifade etme ve sosyal ihtiyaçlarını karşılama aracı olmaktadır. Öte yandan marka kişiliği, markaların da kendilerini ifade etme yöntemidir ve tüketicilerle iletişimlerini biçimlendirmektedir. Markalar, tüketicilerinin zihnindeki kişilikleri aracılığıyla kendilerini anlatabilmekte, farklılaştırabilmekte ve tüketicileriyle yakın ilişki kurabilmektedir (Baştürk, 2009). Ayrıca, marka kişiliği, müşterilerin tercihlerini ve kullanımlarını etkileyerek markaya dair güveni ve bahsedildiği gibi bağılığı arttırabilmektedir (Akar, 2004; Aksoy ve Özsomer, 2007). Bu getiriler, marka kişiliğini, marka değerinin temel boyutlarından biri haline getirmekte (Aaker, 1996) ve güçlü bir marka oluşumunun, düzgün ve etkili bir marka kişiliği tasarlanması ve uygulanması ile mümkün olduğu belirtilmektedir (Keller, 2003).

Marka kişiliğinin oluşumuna katkıda bulunan kaynaklar doğrudan ve dolaylı olmak üzere iki kategoride sınıflandırılmaktadır. Doğrudan kaynaklar; tipik marka kullanıcıları, işletme çalışanları ve CEO'lara dair insani özellikleri içermektedir. Dolaylı kaynaklar ise ürün, fiyat, dağıtım ve tanıtımla ilgili kararlar gibi işletme yöneticileri tarafından yürütülen süreçlerden oluşmaktadır (Aaker, 1997). Bu kapsamda tanımlanan faktörler arasında "kullanıı imgelemeleri", "çalışan imgelemeleri" ve "resmî duyurular/paylaşımlar" yer almaktadır. Anlaşılacağı üzere, kullanıcı ve çalışan imgelemeleri ile bir markanın tipik kullanıcı ve çalışanlarıyla ilişkilendirilen insan karakteristikleri tanımlanırken, resmî duyurular ile tüketicide markaya ilişkin farkındalığın ve olumlu tutumun oluşturulması amacıyla pazarlamacılar tarafından oluşturulan mesajlar tanımlanmaktadır (Schultz, 1992). Sterotipik teoriye göre tüketiciler, markanın çalışanlarının ve kullanıcılarının benzer temel tutumlara/özelliklere sahip olduklarına ilişkin genellenmiş bir fikri benimsemektedir ve tüketicilerin, kullanıcılar ve çalışanlar hakkındaki inançları ilgili marka hakkındaki algılarını etkilemektedir (Wentzel, 2009: 360). Bunun yanında, Sinyal teorisi (signalling theory) ise bir kuruluşun daha yüksek düzeyde sosyal duruş sergilemesini sağlayan sosyal medya sayfasının, insanları kuruluşun daha arkadaş canlısı, yüksek ahlaki ve iyi niyetlere sahip olduğuna inandırabileceğini savunmaktadır (Carpentier, Van-Hoye ve Weijters, 2019: 2). Bu öngörülere paralel olarak, marka kişiliği ile sosyal medyadaki etkenleri arasındaki ilişkiyi inceleyen bir araştırma, kullanııı ve çalışan imgelemelerinin markanın kişiliği üzerinde anlamlı düzeyde olumlu etkiye sahip olduğunu saptamıştır. Ayrıca, resmî duyuruların da marka kişiliği üzerinde anlamlı düzeyde bir yordayıcı etkiye sahip olduğu görülse de bu etkinin, kullanıcı ve çalışan imgelemesine göre daha az düzeyde olduğu belirtilmiştir (Xu vd., 2016).

\subsection{Marka Kişiliği ile Tüketici Satın Alma Niyeti ílişkisi}

Bugün ürünlerin algılanan kalitesi pek değişmemekte ve zor bir yol olsa da farklılaşma için yeni ürün özelliklerinin geliştirilmesine yoğunlaşıımaktadır. Ancak, yeni geliştirilen ürün özellikleri de gelişen teknoloji sayesinde kolayca taklit edilebilmektedir. Bu sebeple olgun ve yoğun pazarlarda markanın konumlandırılması, 
çok çaba harcanmasını, farklılaştırma stratejilerinin kullanımını (Aaker, 1997) ve daha stratejik düşünmeyi (Rajagopal, 2006; 56) gerektirmektedir. Bu noktada, markanın jenerik ad olarak konumlandırıması, sıradan bir şey olarak algılandığından pazar payı kaybına neden olabilmekte, hatta kolay görünse de fiyat farklılaşması göz önüne alındığında, firmanın kontrol mekanizmalarını zayıflatabilmektedir (Aksoy ve Özsomer, 2007). Bunun yerine, bir ürünü farklılaştırmada, duygusal faktörler üzerinde daha fazla durulması gerektiği vurgulanmaktadır. Çünkü, bir markayı veya ürünü konumlandırmada, markayı oluşturan somut ve rasyonel faktörlere göre soyut ve duygusal faktörlerin daha etkili olduğu önerilmektedir (Akın, 2011: 193). Bu doğrultuda, markaya kişilik özellikleri atfedilerek fonksiyonel özelliklerden daha kalıcı olabilecek sembolik anlam veya duygusal değer yüklenebilmektedir (Rajagopal, 2006: 59). Diğer bir deyişle, markalara hissetme özelliği kazandırılarak (Aaker, 1997) tüketici için marka duygusal yarar sağlayan bir arkadaş halini almakta ve marka ile müşteri arasındaki ilişki duygusal bağ çerçevesinde güçlendirilmektedir (Akın, 2011: 199). Tüketici ve marka arasındaki ilişki ne kadar büyükse, markayı tercih etme düzeyi de o oranda artacaktır (Yılmaz, 2007). Yani, markaya atfedilen kişilik sembolik bir kullanımda olsa da tüketici psikolojisinde "ürünün satın almaya değer olup olmadığının" bir göstergesi halini alacaktır (Nart, 2008: 159). Hatta, tüketicinin markayı kişiselleştirmesi, markayla uyum hissetmesi ve bağ kurması halinde tüketici için markanın bağımlıık oluşturması bile olasıdır. Kişiselleştirme ve uyumun sağlanması ise yine marka kişiliğinin geliştirilmesi ile sağlanabilmektedir (Yılmaz, 2007).

Öte yandan, tüketicilerin satın alma tercihleri bilindiği üzere topladıkları bilgilere dayanmaktadır. Ancak, bilgi olmadan satın alma kararı vermek zorunda olan tüketiciler ise belirsizlik nedeniyle kendilerini risk altında hissetmekte ve ipucu arayışına girmektedir. Bu durum, marka ve markanın tüketiciler için anlamının satın alma tercihinde elzem rol üstlenmesine sebep olmaktadır (Dündar Kurtuluş, 2008: 286). Diğer bir deyişle, belirsizlik durumu ürünün tercih edilmesinde marka kişiliğini öne çıkarabilmektedir.

Marka kişiliğine ilişkin pazarlama alanında ortaya çıkan bu kazanımlar, araştırmacıları marka kişiliğinin tüketici satın alma niyeti üzerindeki etkisini incelemeye yöneltmiştir. Bu paralelde yürütülen bir çalışmada, "algılanan marka kişiliği ne kadar olumluysa, bir markanın satın alınma niyetinin de o oranda olası olacağı" hipoteziyle yola çıkılmış ve marka kişiliğinin tüketici satın alma davranışı üzerinde olumlu yönde anlamlı bir etki düzeyine sahip olduğu bulgulanmıştır (Wang, Yang ve Liu, 2009: 208). Elde edilen bu sonuç, yapılan birçok farklı çalışma tarafından desteklenmiştir (Mengxia, 2007: 43; Phau, Chao, Wang ve Yang, 2008; Wang ve Yang, 2008: 469; Akın, 2011: 199-200; Ramaseshan ve Stein, 2014: 675; Toldos-Romero ve Orozco-Gómez, 2015: 472). Destekleyen çalışmalar arasında yer alan ve Ramaseshan ve Stein (2014: 675)'in yürüttükleri araştırma, marka kişiliğinin marka deneyimi ve satın alma niyeti arasındaki ilişkide kısmi aracı rol üstlendiğini göstermiştir. Dahası, şirkete (örneğin, Citroen) atfedilen marka kişiliği özelliklerindense ürüne (örneğin, CocaCola) atfedilen marka kişiliği örüntülerinin satın alma niyeti üzerinde daha olumlu ve anlamlı etkisinin olduğu saptanmıştır (Wang, Yang ve Liu, 2009: 208). Ancak bu durum tabi ki şirkete atfedilen marka kişiliği etkisinin anlamlı olmadığını akla getirmemelidir. Çünkü, Mengxia (2007: 43) tarafından Çinli katılımcıların dahil edildiği ve Nike ile Sony'nin karşılaştırıldığı bir başka çalışma, şirket bazında atfedilen kişilik özelliklerinin bu markaların satın alınma niyetlerini anlamlı düzeyde olumlu yönde etkilediğini kanıtlamaktadır. İki değişken arasındaki bu ilişkinin detayına inildiğinde ise marka kişiliğinin incelenen boyutlarının (yetkinlik, heyecan, maskülinite, gelenekçilik) her birinin markanın satın alınma olasılığı üzerinde olumlu ve anlamlı etkilerinin olduğu, ancak bu boyutlar arasında yetkinlik ve gelenekçilik boyutlarının etkilerinin daha fazla olduğu görülmüştür (Akın, 2011: 199-200).

\subsection{Sosyal Medya Pazarlama Aktiviteleri ile Tüketici Satın Alma Niyeti Arasındaki iliş̧kide Marka Kişiliğinin Aracı Rolü}

Günümüz tüketim şeklinin yalnızca gereklilikler temelinde yol almadığı, sosyal ve sembolik ilişkilerden ve duygulardan beslendiği bilinmektedir (Csikszentmihalyi, 2000: 267). Bahsedildiği gibi, bu durum göz önüne alınarak markalara sembolik anlam ve duygusal değerlerin işlendiği kişilik özellikleri atfedilmekte (Rajagopal, 2006: 59), tüketicilerin duygusal bağ kurduğu arkadaşlıklar edinmesi sağlanmaktadır (Akın, 2011: 199). Ancak, markalara bu kişilik özelliklerinin işlenmesi sürecinde sosyal medya pazarlama aktivitelerinin rol aldığı yürütülen kapsamlı bir çalışmada bulgulansa da farklı çalışmalara intiyaç duyulduğu belirtilmektedir (Xu 
vd., 2016: 444). Diğer yandan, gerek sosyal medya pazarlama aktivitelerinin (Colliander ve Dahlen, 2011; Mao, Zhu ve Sang, 2014; Dehghani ve Tumer, 2015: 600; Gautam ve Sharma, 2017: 884-885; MartínezNavarro ve Bigné, 2017: 64-66; Toor, Husnain ve Hussain, 2017: 187; Alalwan, 2018: 71-73; Harun ve Husin, 2019: 118-120) gerekse marka kişiliğinin (Mengxia, 2007: 43; Phau vd., 2008; Wang ve Yang, 2008: 469; Wang, Yang ve Liu, 2009: 208; Akın, 2011: 199-200; Ramaseshan ve Stein, 2014: 675; Toldos-Romero ve OrozcoGómez, 2015: 472) tüketici satın alma niyeti üzerinde yordayıcı etkisinin olduğu birçok araştırma tarafından gösterilmektedir. Elde edilen bu ilişkilere dair bulgulardan hareketle, sosyal medya pazarlama aktiviteleri ile tüketici satın alma niyeti arasındaki bu ilişkide marka kişiliği faktörünün aracılık edebileceği düşünülmektedir. Diğer bir deyişle, sosyal medya pazarlama aktivitelerinin algılanan marka kişiliğini olumlu yönde etkilediği, tüketici zihninde oluşan olumlu marka kişiliğinin de ilgili markanın satın alınma niyetini arttırdığı önerilmektedir. Ancak, belirtildiği gibi literatürde bu faktörler arasındaki birebir ilişkilerin varlığı vurgulansa da gerek ulusal gerekse uluslararası literatürde faktörlerin birlikte ele alındığı, yani marka kişiliğinin olası aracı etkisinin sınandığı bir çalışmaya rastlanılmamaktadır. Bu sebeple konunun çalışılması gerekli görülmekte ve öncül çalışmalara intiyaç duyulmaktadır.

\section{Sonuç}

İnternet ortamı ve sosyal medya platformları, kullanıcıların, yalnızca sohbetler gerçekleştirebildikleri ya da görüşlerini ifade edebildikleri ortamlardan çok daha fazlasını yapabilecekleri potansiyele sahiptir. Öyle ki kullanııların diğerlerine deneyimlerini aktarabilmesini ve markalarla iletişim kurabilmesini sağlamakta; yani aslında, ilgili markaların popüleritesini desteklemektedir. Bunun yanında, markalar tarafından sosyal medyada gerçekleştirilen etkinlikler ile tüketicilere belirli bir sosyal gruba dahil olma hissi yaşatılabilmektedir. $\mathrm{Bu}$ da tüketicinin markayla duygusal bir bağ kurmasını sağlayabilmekte ve markaya karşı sadakatini destekleyebilmektedir. Madalyonun diğer yüzünden bakıldığında ise bu gelişmelerin, işletmelerin potansiyel müşterilerine ulaşmalarına, onlarla doğru zamanda iletişime geçmelerine ve sonucunda, satış hacimlerini arttırabilmelerine olanak sağlayabildiği görülmektedir. İncelenen çalışmalardan varıldığı üzere, sosyal medya pazarlama faaliyetleri tüketici satın alma niyeti üzerinde olumlu bir etkiye sahiptir. Özellikle, bu etkinin oluşturulmasında yerleşim, deneyimsel pazarlama, etkileşim, kişiselleştirme ve eğlenceye odaklanılmasının ve bloglar ile online dergilerin kullanılmasının gerekli olduğu sonucuna varılabilir. Özellikle de reklamların yaratıcı, ilgi çekici, etkileşimsel ve bilgilendirici bir yapıda kurgulanması ve ilgili ürünün yararına ilişkin algıyı desteklemesi yararlı görülmektedir. Böylece sosyal medya reklamları ile marka imajı ve marka değeri desteklenebilmekte; sonucunda, ilgili markanın satın alınma düzeyi arttırılabilmektedir. Öte yandan, tüketicinin algıladığı değerin, riskin ya da yararın satın alma niyeti üzerindeki etkisi düşünüldüğünde, sosyal medya pazarlama faaliyetleri ile tüketici satın alma niyeti arasındaki bu ilişkide tüketici bazlı etkilerin göz ardı edilmemesi önemli görülmektedir. Özellikle, sosyal medya pazarlama faaliyetlerinin markaya dair tüketici zihninde oluşturabildiği kişiliğin yanında, marka kişiliğinin de ilgili markanın satın alınma niyetine yaptığı katkısı göz önüne alındığında, odağın bu faktörün olası aracı etkisine çevrildiği ve bilimsel çalışmalarla araştırılmasının gerekli olduğu düşünülmektedir.

Literatür taramasına dayalı bu çalışmayla sosyal medya pazarlama aktiviteleri, marka kişiliği ve tüketici satın alma niyeti arasındaki doğrudan ilişkilerin göz önüne çıkarılması ve bu ilişkilere dair detaylı bilgiler sunulması amaçlanmaktadır. Böylece, sosyal medya pazarlama aktiviteleri ile tüketici satın alma niyeti arasındaki ilişkide marka kişiliğinin olası rolünü araştırma ihtiyacı vurgulanarak öncül çalışmalara motivasyon sağlaması beklenilmektedir. Öte yandan, bahsi geçen faktörler arasındaki ilişkilerin farklı sosyoekonomik ve eğitim düzeylerinde değerlendirilmemiş olması, bu çalışmanın bir eksiği olarak düşünülmekte ve bu farklılıkların ileriki çalışmalarda ele alınması önerilmektedir. 


\section{Beyan ve Açıklamalar (Declarations and Disclosures)}

Yazarların Etik Sorumlulukları (Ethical Responsibilities of Authors): Bu çalışmanın yazarları, araştırma ve yayın etiği ilkelerine uyduklarını kabul etmektedirler.

Çıkar Çatışması (Conflicts of Interest): Yazarlar tarafından herhangi bir çıkar çatışması beyan edilmemiştir.

Finansal Destek (Funding): Yazarlar, çalışmanın hazırlanması ve/veya yayınlanması sürecinde herhangi bir finansal destek almamışlardır.

Yazar Katkı Oranı (Author Contributions): Yazarlar, çalışmaya olan katkılarını şu şekilde beyan etmişlerdir: Kavramlaştırma ve çalışma dizaynı, B. Kartal; literatür taraması ve analizi M. S. Şalvarlı; çalışmanın ilk/taslak halinin yazııması, M. S. Şalvarlı; çalışmanın gözden geçirilmesi ve düzenlenmesi/düzeltilmesi, B. Kartal. Çalışmanın ilk ve son hali tüm yazarlar tarafından okunmuş ve onaylanmış olup, yazarlar çalışmalarıyla ilgili sorumluluğu kabul etmektedirler.

intihal Denetimi (Plagiarism Checking): Bu çalışma, intihal tarama programı kullanılarak intihal taramasından geçirilmiştir.

(*) ilave Açıklama (Additional Disclosure): Bu çalı̧̧a, Mustafa Seçkin Şalvarlı tarafından, Manisa Celal Bayar Üniversitesi Sosyal Bilimler Enstitüsü’nde Doç. Dr. Burak Kartal danışmanlığında yürütülen "Sosyal Medya Pazarlama Aktiviteleri ile Tüketici Satın Alma Niyeti Arasındaki Ilişkide Marka Yararı ve Marka Kişiliğinin Etkisi" başlıklı doktora tezinden türetilmiştir.

\section{Kaynaklar}

Aaker, D. A. (1996). Measuring brand equity across products and markets. California Management Review, 38(3), 102120.

Aaker, J. L. (1997). Dimensions of brand personality. Journal of Marketing Research, 34(3), 347-356.

Akar, E. (2004). Sanal ortamda müşteri ilişkileri yönetimi ve THY web sitesinin müşteri memnuniyeti üzerine. Afyon Kocatepe Üniversitesi Sosyal Bilimler Enstitüsü, Yayınlanmamış Doktora Tezi, Afyon.

Akar, E. (2010). Sanal toplulukların bir türü olarak sosyal ağ siteleri: Bir pazarlama iletişim kanalı olarak işleyişi. Anadolu Üniversitesi Sosyal Bilimler Dergisi, 10(1), 107-122.

Akar, E., \& Dalgic, T. (2018). Understanding online consumers' purchase intentions: A contribution from social network theory. Behaviour \& Information Technology, 37(5), 473-487.

Akar, E., \& Nasir, V. A. (2015). A review of literature on consumers' online purchase intentions. Journal of Customer Behaviour, 14(3), 215-233.

Akar, E., \& Topçu, B. (2011). An examination of the factors influencing consumers' attitudes toward social media marketing. Journal of Internet Commerce, 10(1), 35-67.

Akın, M. (2011). Predicting consumers' behavioral intentions with perceptions of brand personality: A study in cell phone markets. International Journal of Business and Management, 6(6), 193-206.

Aksoy, L., \& Özsomer, A. (2007). Türkiye'de marka kişiliğini oluşturan boyutlar. 12. Ulusal Pazarlama Kongresi, 1-11.

Alalwan, A. A. (2018). Investigating the impact of social media advertising features on customer purchase intention. International Journal of Information Management, 42, 65-77.

Avis, M. (2012). Brand personality factor based models: A critical review. Australasian Marketing Journal, 20, 89-96

Barefoot, D., \& Szabo, J. (2010). Friends with benefits: A social media marketing handbook. San Francisco: No Starch Press.

Baştürk, F. (2009). Marka kişilik kuramında arketip yaklaşımı. Marmara Üniversitesi Sosyal Bilimler Enstitüsü, Yayımlanmamış Doktora Tezi, İstanbul.

Bilgin, Y. (2018). The effect of social media marketing activities on brand awareness, brand image and brand loyalty. Business \& Management Studies: An International Journal, 6(1), 128-148.

Carim, L., \& Warwick, C. (2013). Use of social media for corporate communications by research-funding organisations in the UK. Public Relations Review, 39(5), 521-525.

Carpentier, M., Van-Hoye, G., \& Weijters, B. (2019). Attracting applicants through the organization's social media page: Signaling employer brand personality. Journal of Vocational Behavior, 115, 103326.

Chaffey, D., \& Smith, P. R. (2013). eMarketing eXcellence: Planning and optimizing your digital marketing. New York: Routledge. 
Sosyal Medya Pazarlama Aktiviteleri ile Satın Alma Niyeti Arasındaki Ilişkide Marka Kişiliğinin Rolü: Literatür Araştırması

Chaturvedi, S., \& Gupta, S. (2014). Effect of social media on online shopping behaviour of apparels in Jaipur city: An analytical review. Journal of Business Management, Commerce \& Research, 2(7), 1-8.

Chiang, I. P., Wong, R., \& Huang, C. H. (2019). Exploring the benefits of social media marketing for brands and communities. International Journal of Electronic Commerce Studies, 10(2), 113-140.

Chiou, Y. H., Chen, M. H., Huang, L. S., Huang, L. R. and Hu, S. R. (2008). The effects of blog product placement type and source credibility on the attitudes toward product placement in Taiwan. Paper presented at the International Conference on Business and Information (BAl2008). http://academicpapers.org/ocs2/session/Papers/E1/624.pdf (Erişim Tarihi: 24 Aralık 2010).

Clemons, E. K. (2009). The complex problem of monetizing virtual electronic social networks. Decision Support Systems, 48, 46-56.

Colliander, J., \& Dahlen, M. (2011). Following the fashionable friend: The power of social media weighing publicity effectiveness of blogs versus online magazines. Journal of Advertising Research, 51(1), 313-320.

Csikszentmihalyi, M. (2000). The costs and benefits of consuming. Journal of Consumer Research, 27(2), $267-272$.

Çetinkaya, A., \& Özdemir, Z. (2014). Sosyal ağların pazarlama disiplinleri içinde kullanımı: Instagram üzerine bir inceleme. International Academic Conference on Digital Communication Impact, 581-641.

Çizmeci, F., \& Ercan, T. (2015). The effect of digital marketing communication tools in the creation brand awareness by housing companies. Megaron, 10(2), 149-161.

Dehghani, M., \& Tumer, M. (2015). A research on effectiveness of Facebook advertising on enhancing purchase intention of consumers. Computers in Human Behavior, 49, 597-600.

Digital (2020). Global digital overview. https://wearesocial.com/digital-2020 (Erişim Tarihi: 20 Aralık 2020).

Dineva, D. P., Breitsohl, J. C., \& Garrod, B. (2017). Corporate conflict management on social media brand fan pages. Journal of Marketing Management, 33(9-10), 679-698.

Drews, W., \& Schemer, C. (2010). eTourism for all? Online travel planning of disabled people. (Ed.) U. Gretzel, R. Law, \& M. Fuchs, Information and communication technologies in tourism 2010 (pp. 507-518). Vienna: Springer.

Erkan, I., \& Evans, C. (2016). The influence of eWOM in social media on consumers' purchase intentions: An extended approach to information adoption. Computers in Human Behavior, 61, 47-55.

Faqih, K. (2013). Exploring the influence of perceived risk and internet self-efficacy on consumer online shopping intentions: Perspective of technology acceptance model. International Management Review, 9(1), 68-78.

Forbes, L., \& Vespoli, E. (2013). Does social media influence consumer buying behavior? An investigation of recommendations and purchases. Journal of Business \& Economics Research, 11(2), 107-112.

Fotis, J., Buhalis, D., \& Nicos, R. (2012). Social media use and impact during the holiday travel planningprocess.http://eprints.bournemouth.ac.uk/19262/1/Fotis_et_al_2012_Social_media_use_and_impac t_during_the_holiday_travel_planning_process.pdf (Erişim Tarihi: 30 Mart 2016).

Gautam, V., \& Sharma, V. (2017). The mediating role of customer relationship on the social media marketing and purchase intention relationship with special reference to luxury fashion brands. Journal of Promotion Management, 23(6), 872-888.

Gros, C. H. (2012). The influence of social media on consumers during their purchase decisionmaking process and the implications for marketers. Dublin Business School, Unpublished Doctoral Dissertation, Dublin.

Hamid, S., Bukhari, S., Ravana, S. D., Norman, A. A., \& ljab, M. T. (2016). Role of social media in information-seeking behaviour of international students. Aslib Journal of Information Management, 68(5), 643-666.

Harun, A., \& Husin, W. H. R. (2019). Is the purchasing behavior of suburban millennials affected by social media marketing? Empirical evidence from Malaysia. Kome, 7(2), 104-127.

Hennig-Thurau, T., Gwinner, P. G., Walsh, G., \& Gremler, D. D. (2004). Electronic word-of-mouth via consumer opinion platforms: What motivates consumers to articulate themselves on the internet? Journal of Interactive Marketing, $18(1), 38-52$.

Hidayat, A., \& Diwasasri, A. (2013). Factors influencing attitudes and intention to purchase counterfeit luxury. International Journal of Marketing Studies, 5(4), 143-151.

Hill, S., Provost, F., \& Volinsky, C. (2006). Network-based marketing: Identifying likely adopters via consumer networks. Statistical Science, 21(2), 256-276.

Ismail, A. R. (2017). The influence of percieved social media marketing activities on brand loyality: The mediation effect of brand and value consciousness. Asia Paciffic Journal of Marketing and Logistics, 29(1), 129-144. 
Kaplan, A. M., \& Haenlein, M. (2010). Users of the world, unite! The challenges and opportunities of social media. Business Horizons, 53(1), 59-68.

Keller, K. L. (2003). Strategic brand management: Building, measuring and managing brand equity (2nd ed.). New Jersey: Prentice Hall.

Kotler, P., \& Keller, K. L. (2006). Marketing management (12th ed.). New Jersey: Pearson Prentice Hall.

Kozinets, R. V., De Valck, K., Wojnicki, A. C., \& Wilner, S. J. (2010). Networked narratives: Understanding word-of-mouth marketing in online communities. Journal of Marketing, 74(2), 71-89.

Kryvinska, N., Kaczor, S., Strauss, C., \& Gregus, M. (2015). Servitization-transition from manufacturer to service provider. 7. Naples Forum on Service.

Dündar Kurtuluş, S. (2008). Ülkelerin marka kişiliği üzerine bir araştırma. Atatürk Üniversitesi iktisadi ve Idari Bilimler Dergisi, 22(2), 287-300.

Lamberton, C., \& Stephen, A. T. (2016). A thematic exploration of digital, social media, and mobile marketing: Research evolution from 2000 to 2015 and an agenda for future inquiry. Journal of Marketing, 80(6), 146-172.

Luna-Nevarez, C., \& Torres, I. M. (2015). Consumer attitudes toward social network advertising. Journal of Current Issues \& Research in Advertising, 36(1), 1-19.

Mangold, W. G., \& Faulds, D. J. (2009). Social media: The new hybrid element of the promotion mix. Business Horizons, 52(4), 357-365.

Martínez-Navarro, J., \& Bigné, E. (2017). The value of marketer-generated content on social network sites: Media antecedents and behavioral responses. Journal of Electronic Commerce Research, 18(1), 52-72.

Mao, Y., Zhu, J. X., \& Sang, Y. (2014). Consumer purchase intention research based on social media marketing. International Journal of Business and Social Science, 5(10-1), 92-97.

McCrae, R. R., \& John, O. P. (1992). An introduction to the five-factor model and its applications. Journal of Personality, 20, 175-215.

Mengxia, Z. (2007). Impact of brand personality on PALI: A comparative research between two different brands. International Management Review, 3(3), 36-44.

Merisavo, M. (2006). Effects of digital marketing communication on customer loyalty: An integrative model and research propositions. Helsinki: Helsinki School of Economics Working Papers.

Mirabi, V., Akbariyeh, H., \& Tahmasebifard, H. (2015). A study of factors affecting on customers purchase intention. Journal of Multidisciplinary Engineering Science and Technology, 2(1), 267-273.

Mort, G. S., \& Drennan, J. (2002). Mobile digital technology: Emerging issue for marketing. Journal of Database Marketing \& Customer Strategy Management, 10(1), 9-23.

Nambisan, S., \& Baron, R. A. (2007). Interactions in virtual customer environments: Implications for product support and customer relationship management. Journal of Interactive Marketing, 21(2), 42-61.

Nair, M. (2011). Understanding and measuring the value of social media. The Journal of Corporate Accounting \& Finance, $22(3), 45-51$.

Nart, S. (2008). Menşe ülke etkisinin tüketici algılamaları ve davranışlarına yansımaları: İngiltere pazarında Türk ve Alman markalarının karşılaştırılması. Süleyman Demirel Üniversitesi İktisadi ve Idari Bilimler Fakültesi Dergisi, 13(3), 153177.

Neti, S. (2011). Social media and its role in marketing. International Journal of Enterprise Computing and Business Systems, 1(2), 1-15.

Odabaşı, Y., \& Barış, G. (2002). Tüketici davranışı. İstanbul: MediaCat Kitapları.

Özdemirci, A. (2004). Popüler kültür, tüketim psikolojisive imaj yönetimi: Türkiye (1950-1980) İstanbul. Marmara Üniversitesi Sosyal Bilimler Enstitüsü İşletme Anabilim Dalı Yönetim Organizasyon Bilim Dalı, Yayınlanmamış Yüksek Lisans Tezi, İstanbul.

Parsons, A. J., Zeisser, M., \& Waitman, R. (1996). Organizing for digital marketing. The McKinsey Quarterly, (4), $185-192$.

Phau, I., Chao, P., Wang, X., \& Yang, Z. (2008). Does country-of-origin matter in the relationship between brand personality and purchase intention in emerging economies? International Marketing Review, 25(4), 458.

Racolta-Paina, N., \& Luca, T. (2010). Several considerations regarding the online consumer in the 21st century - A theoretical approach. Management \& Marketing, 5(2), 85-100.

Rajagopal, R. S. (2006). Brand excellence: Measuring the impact of advertising and brand personality on buying decisions. Measuring Business Excellence, 10(3), 56-65. 
Ramaseshan, B., \& Stein, A. (2014). Connecting the dots between brand experience and brand loyalty: The mediating role of brand personality and brand relationships. Journal of Brand Management, 21(7-8), 664-683.

Schultz, D. E. (1992). Integrated marketing communications. Journal of Promotion Management, 1(1), 99-104.

Shaharudin, M., Pani, J., Mansor, S., \& Elias, S. (2010). Purchase intention of organic food: Perceived value overview. Canadian Social Science, 6(1), 70-79.

Smith, K. L. (2007). What is digital marketing? http://digitalmarketing101.blogspot.com.tr/2007_09_30_archive.html (Erişim Tarihi: 12 Temmuz 2019).

So, K. K. F., Wu, L., Xiong, L., \& King, C. (2018). Brand management in the era of social media: Social visibility of consumption and customer brand identification. Journal of Travel Research, 57(6), 727-742.

Stephen, A. T. (2016). The role of digital and social media marketing in consumer behavior. Current Opinion in Psychology, 10, 17-21.

Tiago, M. T. P. M. B., \& Veríssimo, J. M. C. (2014). Digital marketing and social media: Why bother? Business Horizons, 57(6), 703-708.

Toldos-Romero, M. D. L. P., \& Orozco-Gómez, M. M. (2015). Brand personality and purchase intention. European Business Review, 27(5), 462-476.

Toor, A., Husnain, M., \& Hussain, T. (2017). The impact of social network marketing on consumer purchase intention in Pakistan: Consumer engagement as a mediator. Asian Journal of Business and Accounting, 10(1), 167-199.

Tuten, T. L. (2008), Advertising 2.0: Social media marketing in a Web 2.0 World. London: Greenwood Publishing Group.

Valette-Florence, P., Guizani, H., \& Merunka, D. (2011). The impact of brand personality and sales promotions on brand equity. Journal of Business Research, 64(1), 24-28.

Venable, B. T., Rose, G. M., \& Gilbert, F. W. (2003). Measuring the brand personality of non-profit organizations. Advances in Consumer Research, 30, 379-380.

Vinerean, S., Certina, I., Dumitrescu, L., \& Tichindelean, M. (2013). The effects of social media marketing on online consumer behavior. International Journal of Business and Management, 8(14), 66-79.

Wallenklint, J. (1998). Brand personality - Brand personality as a way of developing and maintaining Swedish brands. Lulea Tekniska Universitet, Unpublished Master's Thesis, Lulea.

Wang, X., \& Yang, Z. (2008). Does country-of-origin matter in the relationship between brand personality and purchase intention in emerging economies? International Marketing Review, 25(4), 458.

Wang, X., Yang, Z., \& Liu, N. R. (2009). The impacts of brand personality and congruity on purchase intention: Evidence from the Chinese mainland's automobile market. Journal of Global Marketing, 22(3), 199-215.

Wave 8 (2014). The language of concent. http://wave.umww.com/the_wave_story.html (Erişim Tarihi: 3 Ocak 2017).

Wentzel, D. (2009). The effect of employee behavior on brand personality impressions and brand attitudes. Journal of the Academy of Marketing Science, 37(3), 359-374.

Wilson, S. G., \& Abel, I. (2002). So you want to get involved in e-commerce. Industrial Marketing Management, 31(2), 85-94.

Xu, A., Liu, H., Gou, L., Akkiraju, R., Mahmud, J., Sinha, V., Hu, Y., \& Qiao, M. (2016, May). Predicting perceived brand personality with social media. Paper presented at the Tenth International AAAI Conference on Web and Social Media, https://www.aaai.org/ocs/index.php/ICWSM/ICWSM16/paper/view/13078 (Erişim Tarihi: 30 Mart 2018).

Yılmaz, M. (2007). Marka kişiliği boyutları ve IKEA uygulaması. Yıldız Teknik Üniversitesi, Sosyal Bilimler Enstitüsü, Yayınlanmamış Yüksek Lisans Tezi, İstanbul.

Zhou, L., \& Wang, T. (2014). Social media: A new vehicle for city marketing in China. Cities, 37, 27-32. 